Tomasz Kurdyła

Uniwersytet Jagielloński, Kraków

tomasz.kurdyla@gmail.com

\title{
PRAGMATYKA \\ W KLASYFIKACJI SŁOWOTWÓRCZEJ RZECZOWNIKA
}

Słowa klucze: słowotwórstwo, funkcje słowotwórstwa, funkcje formantów, pragmatyka słowotwórcza, klasyfikacja słowotwórcza, ekspresywność, stylistyka, funkcja poetycka

Keywords: word formation, functions of word formation, functions of word-formative affixes, word formation pragmatics, word-formative classification, expressiveness, stylistics, poetic function

1. Pojęcie funkcji pragmatycznej formantu pojawiło się w polskim słowotwórstwie rzeczownikowym dość dawno, jednak do początku lat 8o. XX w. pozostawało ono $\mathrm{w}$ zasadzie nienazwane, to jest nie posługiwano się terminem funkcja pragmatyczna formantu. Pragmatykę słowotwórczą określano najczęściej za pomocą terminów związanych z pojęciami ekspresji językowej i stylu językowego. Mówiono zatem o funkcji ekspresywnej i stylistycznej formantu oraz o derywatach i formantach ekspresywnych lub stylistycznych. Zakres tego pojęcia obejmował na ogół derywaty tradycyjnie zaliczane do deminutywów i augmentatywów (np. kotek, psisko) oraz ekspresywów (np. pisarzyna, nochal) (por. Heltberg 1964; Reczek 1968), ale także formacje typu mieszanego, mutacyjno-modyfikacyjne (np. czarnuch 'murzyn', pijus 'alkoholik') i transpozycyjno-modyfikacyjne (np. pisanina, gadanina) (por. GWJP). Co prawda, w przeszłości używano w słowotwórstwie terminów pragmatyka lub pragmatyczny, lecz nie odnoszono ich do formantu ani do jego funkcji. Jadwiga $\mathrm{Pu}$ zynina wykorzystała pragmatykę $\mathrm{w}$ procedurze ustalania pochodności słowotwórczej (1972), Renata Grzegorczykowa w pracy poświęconej wyrażeniom ekspresywnym wiązała pragmatykę z semantyką takich wyrażeń (1978), a Maria Honowska 
wyróżniła formacje o funkcji pragmatycznej, charakterystyczne dla języka potocznego, przy czym rozumiała je dość osobliwie ${ }^{1}$ (1979: 64-67).

Termin funkcja pragmatyczna formantu został wprowadzony do słowotwórstwa polskiego przez Stanisława Grabiasa (1981b) ${ }^{2}$. W oparciu o semiotyczną triadę Charlesa Morrisa (znak - rzeczywistość - użytkownik)3 uczony wyróżnił funkcje formantu w relacji syntaktycznej, semantycznej i pragmatycznej, czyli w relacji formantu do: podstawy słowotwórczej, desygnatu/denotatu derywatu oraz do użytkownika języka. Funkcję pragmatyczną pełnią formanty, które wnoszą do derywatu element wartościujący o charakterze ekspresywnym (emocjonalnym, np. babsko, lub intelektualnym, np. śpioch 'ten, kto za dużo śpi') i/lub metajęzykowym (stylistycznym), np. podstawówka, wykon. W jednym formancie spotykają się funkcje z trzech poziomów, dlatego też metoda słowotwórcza powinna posługiwać się analizą składnikową, służącą wykryciu wszystkich funkcji danego formantu. Mimo swojej wartości propozycja S. Grabiasa nie znalazła szerszego zainteresowania w środowisku polonistycznym, po części chyba ze względu na zbyt skomplikowaną analizę słowotwórczą (a tym samym małą jej przydatność w nauczaniu akademickim).

Termin funkcja pragmatyczna formantu powraca w podręczniku Alicji Nagórko (2007), przy czym badaczka klasyfikację funkcji formantów opiera na koncepcji słowotwórstwa autorstwa Eleny Ziemskiej. Mimo to jej podziały mają wiele cech wspólnych z taksonomią S. Grabiasa. Jedną z nich jest wielopoziomowość opisu, polegająca na tym, że funkcje formantów określa się ze względu na relacje, $w$ jakich one występują. W książce A. Nagórko są to relacje: semantyczna (znaczenie derywatu - znaczenie podstawy), tekstowa (znaczenie derywatu - parafraza słowotwórcza) oraz pragmatyczna (derywat - użytkownik). Ponadto A. Nagórko, podobnie jak S. Grabias, wydziela zarówno formacje $\mathrm{z}$ formantami o funkcji wyłącznie pragmatycznej, jak i formacje mieszane, w których obok funkcji pragmatycznej występuje funkcja z poziomu semantycznego. Także zakres pragmatyki słowotwórczej jest u obojga autorów podobny, A. Nagórko do formacji pragmatycznych zalicza bowiem formacje ekspresywne (służące wyrażaniu emocji i wartościujące) oraz stylistyczne. U Nagórko

1 Przede wszystkim oddzieliła je od formacji o funkcjach ekspresywnych (i referencjalnych). Według definicji badaczki jest to funkcja „zmierzająca do zapewnienia skuteczności odbioru, skuteczności przebiegu komunikacji”, a formacje o funkcji pragmatycznej mają na celu „przełamać bierność odbiorcy”, skoncentrować jego uwagę na tekście (Honowska 1979: 84). Dlatego funkcję tę nazwała autorka również funkcją reklamy lub funkcją pragmatyczną reklamową derywatów. Należą do nich formacje „niejasne”, zwłaszcza asocjacyjne, oparte na metaforze (typu mrówkowiec). Więcej na ten temat w artykule Krystyny Waszakowej w tym zeszycie „LingVariów”.

2 Koncepcji S. Grabiasa ani następnej - Alicji Nagórko - nie przedstawiam tutaj szczegółowo, ponieważ obydwie są doskonale znane badaczom słowotwórstwa, a obszerniejsze ich omówienie znajdzie czytelnik w (Skarżyński 1999).

3 W tym miejscu należy podkreślić, że pojęcie pragmatyki w słowotwórstwie niemal zawsze nawiązuje do tego tradycyjnego, a nie współczesnego znaczenia pragmatyki, choć czyni się próby łączenia obydwu koncepcji, por. (Nagórko 2007: 222). 
w obszarze pragmatyki słowotwórczej mieszczą się także różnego rodzaju gry językowe i neologizacja o charakterze częściowo tylko słowotwórczym, np. reinterpretacje słowotwórcze typu ciężarówka 'kobieta ciężarna', odważnik 'człowiek odważny', kierownica 'kobieta kierownik'; podobne zjawiska, służące między innymi komizmowi, badał również S. Grabias $(1978 ; 1981 a)$. W derywatach tego typu udział słowotwórstwa ogranicza się - jak sygnalizuje ich nazwa - do procesów wyłącznie interpretacyjnych, znaczeniowych. Formacje takie jak ciężarówka nie są przecież neologizmami morfologicznymi, lecz neologizmami semantycznymi, czyli neosemantyzmami (podobnymi nieco do paronimów typu małżowina 'małżonka', antykwariat 'małżeństwo nierówne stażem - ona antyk, on młody - wariat’; przykłady S. Grabiasa).

2. Potrzebę włączenia funkcji pragmatycznej do klasyfikacji słowotwórczej dostrzegają inni badacze (por. Skarżyński 1999), najnowszą zaś propozycję w tej dziedzinie stanowi klasyfikacja Iwony Kaproń-Charzyńskiej, przedstawiona w kilku artykułach, spośród których dwa wydają się tutaj najważniejsze: Pragmatyczna funkcja formantów w opisie derywatów (2007) i Klasyfikacja derywatów ze względu na funkcje formantów (2008); trzeba je omawiać oddzielnie, ponieważ różnią się nieco w interpretacji istotnych zjawisk słowotwórczych. W artykule z $2007 \mathrm{r}$. autorka, wzorem wspomnianej już E. Ziemskiej, wyraźne odróżnia funkcje formantów od funkcji słowotwórstwa. Temu ostatniemu przypisuje trzy funkcje: 1) semantyczną (inaczej nominatywną, ponieważ wynika ona z potrzeb nominatywnych), 2) gramatyczną (której celem jest zmiana kategorii części mowy derywatu) i 3) pragmatyczną, która realizuje się w trzech odmianach: jako funkcja ekspresywna, stylistyczna (rozumiane podobnie jak u wcześniejszych autorów) oraz poetycka, definiowana $\mathrm{w}$ duchu jakobsonowskim, jako tworzenie znaków „nieprzezroczystych"4 (Kaproń-Charzyńska 2007: 154). Mimo akcentowania różnic między funkcjami słowotwórstwa a funkcjami formantów autorka jednocześnie (słusznie zresztą) wiąże je ze sobą, czyni to jednak dość ogólnie, stwierdzając: „W kontekście podanych funkcji słowotwórstwa proponuje się wyróżniać następujące funkcje formantów” (ibid.: 154). Wydaje się, że funkcje formantów są przez badaczkę rozumiane jako swego rodzaju konkretyzacje funkcji słowotwórstwa, przejaw ich działania na poziomie konkretnych derywatów i kategorii słowotwórczych. Autorka wyróżnia bowiem: 1) funkcję gramatyczną formantu (odpowiadającą klasycznej ${ }^{6}$ funkcji transpozycyjnej),

4 Jakobson mówi o „wysuwaniu wyczuwalności znaku” (Jakobson 1989: 86). Przypomnijmy, że idzie tu o szerokie rozumienie funkcji poetyckiej i poetyckości tekstu, które nie ograniczają się do tekstów poetyckich, literackich. Na przykład funkcję poetycką pełnią frazeologizmy zarówno w tekście piosenki: Tramwaj bez pardonu hulnął i odebrał mi głowę, więcej moja głowa w tramwaju nie postanie, jak i w tekście reklamy: Postaw swoja twarz na nogi (reklama balsamu po goleniu).

5 W artykule z 2008 r. autorka pisze o funkcji „syntaktycznej” (2008: 284), natomiast w artykule z roku 2007 o funkcji gramatycznej, której „rodzajem jest funkcja syntaktyczna” (2007: 154).

6 Pisząc o klasycznych funkcjach formantów i o klasycznym słowotwórstwie, mam na myśli model dokulilowski w postaci rozwiniętej przez tzw. szkołę warszawską. 
2) semantyczną przedmiotową (odpowiada funkcji mutacyjnej odrzeczownikowej), 3) semantyczną jakościową (odpowiada funkcji modyfikacyjnej), 4) pragmatyczną ekspresywną i 5) pragmatyczną stylistyczną - pierwsza polega na „ujawnianiu postaw emotywno-oceniających nadawcy”, druga zaś służy „przełączaniu rejestrów i sygnalizowaniu poziomu dyskursu" (Kaproń-Charzyńska 2008: 284). Brak wśród funkcji formantów funkcji poetyckiej, do czego wrócę w dalszej części artykułu.

Prócz wyżej wymienionych pojawia się w omawianych artykułach funkcja strukturalna; w artykule $\mathrm{z} 2008 \mathrm{r}$. występuje ona jako jedna $\mathrm{z}$ pięciu funkcji formantów ${ }^{7}$, lecz brak jej wśród nich w tekście z 2007 r. - wspomniana została w innym miejscu. Funkcja strukturalna nie łączy się - jak pozostałe funkcje formantów - z funkcjami słowotwórstwa i nie znajduje odzwierciedlenia w klasyfikacji formacji słowotwórczych. Możliwe, że przyczyną tego stanu rzeczy jest dostrzeżona przez I. Kaproń-Charzyńską niesamodzielność funkcji strukturalnej, której zawsze towarzyszy inna funkcja. Inaczej niż badaczka, sądzę, że funkcję strukturalną da się wywieść z funkcji słowotwórstwa. Wynika ona z najważniejszego i najogólniejszego celu derywacji, którym jest tworzenie słów, nowych struktur leksykalnych (tutaj - rzeczowników). Funkcja strukturalna jest zarówno przyczyną, jak i skutkiem słowotwórstwa.

Funkcja strukturalna jest niesamodzielna, za to obligatoryjna dla wszystkich derywatów $(2007,2008)$. Za taką w artykule z 2007 r. uznano także funkcję stylistyczną („każdemu formantowi można przypisać określoną wartość stylistyczną” - s. 152), jednak w artykule z roku 2008 funkcja pragmatyczna (zatem także stylistyczna) została określona jako fakultatywna, nieobowiązkowa. Ku temu ostatniemu osądowi sam również się skłaniam, przy czym lepiej mówić po prostu o formacjach stylistycznie neutralnych, nienacechowanych (które odróżnia się od formacji stylistycznie nacechowanych) niż o formacjach „nacechowanych neutralnie”. Koncepcję stylistycznej funkcji formantu rozwija autorka w artykule z $2011 \mathrm{r}$. (prezentującym wartościowe i ważne postulaty metodologiczne), nie rozstrzyga w nim jednak omawianej tu kwestii. Wydaje się też, że za formanty o funkcji stylistycznej uznaje wyłącznie te morfemy, które „determinują pod względem stylistycznym podstawę”, czyli zmieniają wartość stylistyczną derywatu względem niej (Kaproń-Charzyńska 2011: 62). Co za tym idzie, wzmacnianie wartości stylistycznej podstawy przez formant (analogicznie jak wzmacnianie ekspresji emocji w derywatach typu koteczek) nie zostanie uznane za przejaw funkcji stylistycznej. W pracy z $2011 \mathrm{r}$. również opowiedziałem się za taką interpretacją, jednak obecnie uznaję, że formanty w derywatach typu pasteryzacja, kognitywistyka, ustawka, cienizna, wzmacniając wartość stylistyczną podstawy, pełnią funkcję stylistyczną, podobnie jak w derywatach typu koteczek, tatuś, pijaczysko formanty, wzmacniając wartość emocjonalną podstawy, pełnią funkcję ekspresywną.

Na podstawie funkcji formantów buduje I. Kaproń-Charzyńska klasyfikację formacji słowotwórczych. Istnieją więc: 1) derywaty transpozycyjne (formacje $\mathrm{z}$ for-

7 Funkcji pragmatycznej nie rozbija tam autorka, jak w artykule z 2007 r., na ekspresywną i stylistyczną. 
mantami o funkcji gramatycznej, np. mówienie $\leftarrow$ mówić), 2) derywaty mutacyjne (formanty o funkcji semantycznej przedmiotowej, np. filolog $\leftarrow$ filologia, kottownia $\leftarrow$ kocioł), 3) derywaty modyfikacyjne (formanty o funkcji semantycznej jakościowej, np. pisarka $\leftarrow$ pisarz) i 4) derywaty pragmatyczne (formanty o funkcji ekspresywnej i stylistycznej, np. bieganko $\leftarrow$ bieganie, brzuś $\leftarrow$ brzuch, merc $\leftarrow$ mercedes, stronica $\leftarrow$ strona). Autorka jednoznacznie opowiada się za wydzielaniem tak zwanych derywatów mieszanych (ściślej derywatów o mieszanych funkcjach formantów) i wyróżnia: 5) derywaty mutacyjno-transpozycyjne (pisarz $\leftarrow$ pisać), 6) derywaty mutacyjno-pragmatyczno-transpozycyjne (np. modnisia $\leqslant$ modna, leniuch $\leftarrow$ leniwy, 7) derywaty modyfikacyjno-pragmatyczne (np. gmaszysko $\leftarrow$ gmach, siostrzyczka $\leftarrow$ siostra).

Wprowadzenie do klasyfikacji derywatów o formantach wielofunkcyjnych ${ }^{8}$ uważam za rzecz słuszną, która powinna znaleźć miejsce tak w opisach słowotwórczych, jak i w dydaktyce akademickiej. Wielofunkcyjność formantów (w obrębie kategorii i derywatu)' , a także innych środków językowych, to zjawisko zupełnie naturalne i powszechne w języku. Możliwość pełnienia przez formanty jednocześnie dwóch różnych przyczynowo funkcji, co prowadzi do powstawania mieszanych klas derywatów, nie jest niczym innym, jak przejawem ścierania się w słowotwórstwie tendencji do ekonomizacji języka i jego precyzowania. Jednakże klasy formacji „mieszanych”, zaproponowane przez I. Kaproń-Charzyńską, budzą zastrzeżenia.

Do pierwszej z nich należą derywaty mutacyjne tworzone od podstaw innych niż rzeczowniki, np. pisarz. Czy da się w jednym derywacie połączyć transpozycję (to samo, co podstawa) z mutacją (co innego niż podstawa)? Bynajmniej, zwłaszcza że zmiana kategorii leksykalnej w derywatach tego typu nie wynika z potrzeb derywacji (jak w formacjach transpozycyjnych). Jest to cecha co prawda niezbędna, lecz niejako wtórna z punktu widzenia potrzeb słowotwórczych, ponieważ podstawową przyczyną powstania derywatów typu pisarz jest nominacja, tworzenie nazw dla pojęć dotychczas nienazwanych (innych od pojęć nazywanych podstawami), co w słowotwórstwie rzeczownikowym skutkuje utworzeniem rzeczownika. Innymi słowy, transpozycja wynika tu z funkcji strukturalnej formantu, ta zaś jest obligatoryjna dla wszystkich formantów. Natomiast słowotwórstwo transpozycyjne ma na celu urzeczownikowienie pojęć wyrażanych podstawowo za pomocą czasownika, przymiotnika i liczebnika, funkcja gramatyczna jest zatem przyczyną powstania wyłącznie derywatów transpozycyjnych. Ponadto transpozycja ma na celu zmianę funkcji składniowej podstawy, mutacja - nie. Wszystkie te sprzeczności mają jedno

8 Wielofunkcyjność jako cecha rodzajowa wszystkich bez wyjątków formantów jest podstawą koncepcji S. Grabiasa.

9 Nie należy mylić jej z wielofunkcyjnością formantów, np. sufiksu -ka, por. wyżerka (odczasownikowa nazwa czynności), czerwonka (odprzymiotnikowa nazwa predykatowa), piatka (odliczebnikowa nazwa liczby), podstawówka (uniwerbizacja), lampka (deminutywum), blacharka (odrzeczownikowa nazwa zawodu), kładka (odczasownikowa nazwa wytworu), ścierka (odczasownikowa nazwa narzędzia), rączka 'uchwyt' (odrzeczownikowa nazwa symilatywna). 
źródło, pomieszanie transpozycji i funkcji gramatycznej z nominalizacją i funkcją strukturalną.

Dyskusyjna jest także klasa trzecia, tworzona przez derywaty deminutywne i augmentatywne, w których (zdaniem autorki) nie da się oddzielić znaczenia 'rozmiaru' od komponentów wartościujących (emocjonalnych) (Kaproń-Charzyńska 2007: 155). Po pierwsze, nie wiadomo, czy zdaniem autorki są też inne rodzaje derywatów modyfikacyjno-pragmatycznych, po drugie zaś, derywaty o znaczeniu wyłącznie deminutywnym istnieją w polszczyźnie, np. wieżyczka, patelka, tyżeczka, nożyk, bateryj$k a, k w a d r a c i k$, słupek, plamka itp. Oczywiście niektóre z tych derywatów posiadają dodatkowe znaczenia, np. wieżyczka 'element czołgu' (symilatywum), inne zaś mogą funkcjonować jako warianty w pewnym sensie stylistyczne, co widać na przykładzie takich użyć derywatów, jak w dialogu: A. Tereniu, podaj patelkę! B. Duża, czy matą? A. $\boldsymbol{D} \boldsymbol{u} \dot{z} \mathfrak{q}^{10}$. Wydaje się natomiast, że w derywatach tego typu ekspresja kontekstowa wystąpić może jedynie wyjątkowo, akcydentalnie, oraz w sytuacjach, gdy używane są one jako tzw. nomina deliciarum właściwe (masełko, chlebek) i pozorne (pieniążki). Trudniej odnaleźć przykłady derywatów o funkcji czysto powiększającej, co wynika $\mathrm{z}$ faktu, iż przyrostki augmentatywne służą jednocześnie derywacji ekspresywnej (por. derywaty augmentatywne i ekspresywne na -sko, -isko, -idło, -uch, -al), podczas gdy deminutywa urabiane są podstawowo formantami wielofunkcyjnymi -ek//-ik, -ka, -ko. Za formacje czysto augmentatywne można by uznać leksemy typu $m \nmid o t \leqslant m ł o t e k$, donica $\leftarrow$ doniczka, poducha $\leftarrow$ poduszka pod warunkiem, że zgodzimy się na taki kierunek motywacji (por. GWJP: 427).

3. A zatem propozycja I. Kaproń-Charzyńskiej polega na przekształceniu klasycznej triady słowotwórczej (mutacja, modyfikacja, transpozycja) w układ czteroelementowy, wzbogacony ponadto formacjami mieszanymi. Funkcje pragmatyczne nie są sekundarne wobec funkcji semantycznej czy transpozycyjnej (zwłaszcza, że istnieją derywaty pełniące wyłącznie funkcję pragmatyczną), nie oznacza to jednak, iż należy formacje pragmatyczne wydzielać obok mutacji, modyfikacji i transpozycji. Ich miejsce w klasyfikacji słowotwórczej znajduje się gdzie indziej. Aby jednak należycie wyjaśnić proponowaną tu taksonomię, należy wpierw przedstawić teoretyczne podstawy podziału formacji słowotwórczych ${ }^{11}$. Od zawsze najważniejszym kryterium klasyfikacji słowotwórczej w polskim słowotwórstwie jest funkcja formantu. Ogólne i szczegółowe funkcje formantów wynikają z funkcji i zadań samego słowotwórstwa, które służy zasadniczo dwóm celom - nominacji i renominacji. Nominacja to ustalenie ekwiwalentu słownego dla pojęcia powstałego na podstawie interpretacji

10 O rozumieniu stylistycznej wartości takich derywatów zob. (Kurdyła 2011b).

11 Obszerniej swoje poglądy na słowotwórstwo rzeczownikowe i klasyfikację derywatów przedstawiam w (Kurdyła 2011a); zaproponowana tam klasyfikacja odnosi się do materiału gwarowego i różni się nieco od klasyfikacji prezentowanej w niniejszym artykule. 
danego fragmentu rzeczywistości, które wcześniej nie było wyróżnione językowo, czyli nie miało nazwy. Ten obszar słowotwórstwa ma wybitnie semiotyczną naturę, dlatego wynikającą z niej funkcję formantów można nazwać funkcją no m in acyjną, zaś derywaty będące jego produktami - formacjami nominacyjnymi (lub tradycyjnie - mutacyjnymi).

Jednak w językowym stemplowaniu świata nie zamyka się działalność słowotwórcza, a najlepszym przykładem derywacji niemającej uzasadnienia w nominacji, są formacje transpozycyjne. Funkcja tworzących je formantów polega na zmianie właściwości składniowych (a co za tym idzie, również tekstowych) nazwanego już pojęcia, a więc na nominalizacji, czyli na nadawaniu kształtu rzeczownika predykatom czasownikowym, przymiotnikowym lub liczebnikowym ${ }^{12}$ (por. Nagórko 2007: 225). Owa zmiana sprowadza się do wymiany kategorii gramatycznych właściwych czasownikom, przymiotnikom lub liczebnikom na kategorie rzeczownikowe, dzięki czemu dane pojęcie może występować w tekście w różnych pozycjach i funkcjach składniowych, a zatem zwiększają się możliwości jego językowej konkretyzacji $\mathrm{w}$ tekście (przypomnijmy jednak, że zmianom tym zawsze towarzyszą pewne transformacje semantyczne).

Słowotwórstwo służy także uściślaniu znaczenia podstawy słowotwórczej w derywatach ze względu na takie cechy, jak: wiek, płeć, wielkość, ilośćc oraz jakość (nazwy gatunkowe typu farbka 'rodzaj farby', jęzor 'język (niektórych) zwierząt', liścień 'liść zarodkowy'). W derywatach powstałych dla zaspokojenia tych potrzeb formanty pełnią funkcję modyfikacyjną gatunkową - albowiem wszystkie formacje modyfikacyjne to nazwy gatunkowe sensu largo ${ }^{14}$, tyle że niektóre z nich są w miarę regularne oraz kategorialne, dlatego wyodrębnia się je w kategorie słowotwórcze.

Nowe leksemy powstają również z potrzeby ekspresji sądów wartościujących (opartych na kryterium dobry/zły) i emocjonalnych (przyjemny/nieprzyjemny) oraz ekspresji sądów o charakterze metajęzykowym (przypisywanie słowom określonej wartości stylistycznej). Derywacja leksemów pragmatycznych zasadniczo nie różni się od derywacji modyfikacyjnej typu gatunkowego, ponieważ w obydwu przypadkach podstawowy proces słowotwórczy jest taki sam. Polega on na uściśleniu znaczenia podstawy, tyle że precyzowanie pragmatyczne odbywa się przy użyciu innych kryteriów modyfikacji semantycznej, kryteriów o charakterze nie obiektywnym, empirycznym, lecz subiektywnym i aksjologicznym, emocjonalnym i językowym. Dlatego formacje pragmatyczne uznaję nie za odrębny i „nowy” typ formacji słowotwórczych, lecz za odmianę słowotwórczej modyfikacji, funkcję zaś formantów

12 Do transpozycji odliczebnikowych należą nazwy liczb i numerów typu piątka (dzieci), trzydziestka ósemka 'rozmiar czegoś, numer czegoś'.

13 O podstawach zaliczenia kolektywów do modyfikacji zob. (Rogowska 1993).

14 W odróżnieniu od wspomnianych wyżej modyfikacji gatunkowych sensu stricto, typu jęzor, liścień. 
$\mathrm{w}$ takich derywatach nazywam funkcją modyfikacyjną pragmatyczną. Pod tym względem pozostaję $\mathrm{w}$ zgodzie $\mathrm{z}$ autorkami opracowania słowotwórstwa rzeczownikowego w „żółtej gramatyce” (choć oczywiście nie mówi się tam o funkcji pragmatycznej formantu), gdzie nazwy ekspresywne zaliczono do modyfikacji.

Wspólną cechą przedstawionych wyżej celów derywacji jest nie tyle nazywanie pojęć, ile renominacja pojęć już wyróżnionych językowo, ich ponowne „ujęzykowienie" przez doprecyzowanie znaczenia tematu słowotwórczego ${ }^{15}$. Oczywiście rezultatem renominacji - tak samo jak nominacji - jest leksem, znak (inaczej nie można w ogóle mówić o słowotwórstwie), jednak różne są relacje leksykalne łączące derywaty tych klas z ich podstawami. Otóż transpozycje i modyfikacje obydwu rodzajów to synonimy lub hiponimy względem swoich podstaw, dlatego można ich czasem używać wymiennie, a ich desygnaty mogą być identyczne. Natomiast relacje nominacji (mutacji) do własnych podstaw mają charakter wyłącznie słowotwórczy, derywaty i podstawy nie są synonimami i nie mogą być używane wymiennie, ich desygnaty zaś nigdy nie są tożsame. Można przyjąć, że formanty w transpozycji i modyfikacji mają funkcje pokrewne morfemom gramatycznym, które nie służą tworzeniu leksemów, lecz ich szeroko pojmowanej modyfikacji - ustalane przez końcówki fleksyjne kategorie liczby, przypadka, czasu, stopnia itd. nie tylko pozwalają wyrazom wchodzić w różnorakie związki syntaktyczne, lecz także uściślają ich znaczenie.

Główna linia podziału formacji słowotwórczych jest zatem wyznaczana przez ogólne funkcje słowotwórstwa. W ten sposób formacje modyfikacyjne gatunkowe i pragmatyczne, a także transpozycyjne, jako akty renominacji słowotwórczej, należą do jednej nadrzędnej klasy i przeciwstawiają się jednocześnie mutacjom - formacjom powstałym z przyczyn nominacyjnych, nazewniczych. Dla ścisłości tylko przypomnę, iż w klasycznym słowotwórstwie formacje mutacyjne wraz z modyfikacyjnymi, czyli derywaty z formantami o funkcji semantycznej, przeciwstawia się transpozycjom, derywatom $z$ formantami o funkcji wyłącznie gramatycznej. Jednak w (GWJP: 378$)$ pojawia się zdanie, które zdaje się potwierdzać słuszność proponowanego tu podziału:

Derywaty mutacyjne stanowią wynik rzeczywistej operacji nominacyjnej (nazwotwórczej) w odróżnieniu od transpozycji, która jest przekształceniem na potrzeby czysto składniowe, i modyfikacji, która zasadniczo nie derywuje nowej nazwy, ale doprecyzowuje znaczenie podstawowego leksemu (wyróżnienie - T.K.).

Za oddzieleniem modyfikacji i transpozycji od mutacji przemawiają inne jeszcze względy. Otóż liczba formantów i typów słowotwórczych renominacyjnych jest znacznie mniejsza niż w derywacji nominacyjnej. Dlatego derywacja transpozycji, podobnie jak większości formacji modyfikacyjnych, a inaczej niż derywacja for-

15 W taki sposób badacze ujmują modyfikację, por. (Nagórko 2007: 220; Grabias 1981b: 141; Awdiejew, Habrajska 2004: 188). 
macji nominacyjnych, ma charakter bardziej gramatyczny, to jest regularny i kategorialny. Formacje renominacyjne mogą być derywowane ad hoc, doraźnie, bez większych ograniczeń, ponieważ od wszystkich chyba czasowników da się tworzyć substantiva verbalia (Por. transpozycje typu zrezygnowanie zamiast rezygnacja, przelatywanie zamiast przelot, sprzedawanie obok sprzedaż), podobnie będzie ze zdrobnieniami czy spieszczeniami, por. też w miarę swobodne mnożenie „nowych” feminatywów typu architektka, pedagożka, filolożka, ministra ${ }^{16}$. Natomiast spontaniczne, swobodne tworzenie mutacji najczęściej budzi poczucie, że dany derywat jest neologizmem (por. Puzynina 1967: 96; Kleszczowa 1981: 19), nieznajdującym potwierdzenia w uzusie wyrazem, którego nie znajdzie się w słowniku ${ }^{17}$. Co prawda, poświadczenie słownikowe nie jest tu rozstrzygające, słowniki bowiem nie notują także licznych feminatywów ani zdrobnień, nie czynią tego jednak głównie z powodów technicznych (znacznie zwiększałoby to objętość leksykonów). W miarę swobodna derywacja może dotyczyć także mutacji, lecz tylko typów produktywnych, a właściwie produktywnych serii derywacyjnych, podczas gdy renominacje takich ograniczeń nie mają.

Relacje między poszczególnymi typami formacji i ich podstawami obrazuje poniższy schemat, w którym sześciokąt oznacza podstawę słowotwórczą, a okręgi przedstawiają derywaty (struktury dwudzielne, złożone ze znaczenia tematu słowotwórczego i znaczenia formantu, czyli wartości kategorialnej). Większe okręgi symbolizują centrum znaczeniowe derywatu (i nadrzędność elementu w strukturze derywatu), mniejsze zaś - składniki semantyczne precyzujące (i podrzędność elementu w strukturze derywatu). Okręgi niebieskie to symbole tematów słowotwórczych, okręgi czerwone - formantów mutacyjnych, zielone - formantów modyfikacyjnych; czarny okrąg oznacza transpozycję. Wszystkie okręgi leżące poza sześcianem są tym, co różni derywat od podstawy, są to jednak raczej reprezentacje semantyczno-funkcjonalne formantów (wartości kategorialne) niż formaty jako takie. Zielone okręgi przy renominacji symbolizują renominację złożoną (zob. niżej), czyli derywację leksemów typu cienizna (transpozycja + styl), kotek (kot + młody + mały + melioratywność). Nieco inaczej przedstawiono formacje mieszane typu nominacyjno-modyfikacyjnego, np. pracuś (osoba - nosiciel cechy + melioratywnośćl

16 Wyjątkiem wśród modyfikacji są przede wszystkim nazwy zbiorowe, będące klasą stosunkowo nieliczną i mało produktywną, niektóre feminatywa (i nazwy męskie od żeńskich) oraz nazwy zdrabniające i spieszczające - w ich przypadku na przeszkodzie swobodnej derywacji stoją względy

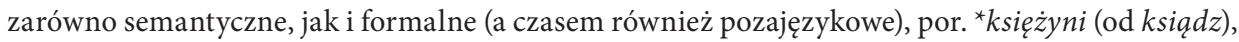
${ }^{*}$ przedszkolanek (od przedszkolanka), ${ }^{\star}$ burzka, ${ }^{\star}$ gniewek, ${ }^{*}$ pociążek // ${ }^{*}$ pociagik (zob. m.in. Jadacka 1994).

17 Mimo to pozostanie on w jakimś stopniu zrozumiany - na poziomie słowotwórczym (znaczenia słowotwórczego), o czym decyduje analogia słowotwórcza. Jesteśmy przecież w stanie odgadnąć bardzo ogólne, słowotwórcze znaczenia nigdy wcześniej niepoznanych derywatów ${ }^{*}$ mizernik, ${ }^{\star}$ kafelkowiec, ${ }^{\star}$ naprawca, załyżnik (ostatni rzeczownik znany jest gwarom). 
pejoratywność), modnisia (osoba - nosiciel cechy + żeńskość + pejoratywnośćc ${ }^{18}$ ). Zielone okręgi nie zostały połączone $\mathrm{w}$ nich ani $\mathrm{z}$ tematem słowotwórczym, ani $\mathrm{z}$ wartością kategorialną, ponieważ symbolizowane przez nie kategorie modyfikacyjne odnoszą się do znaczenia derywatu jako całości ('osoba uważana za pracującą więcej niż inne', 'uszczypliwie o kobiecie przesadnie dbającej o modę, czyli o strój i wygląd').

Schemat 1: Podział derywatów ze względu na funkcje formantów oraz relacje derywatów do ich podstaw słowotwórczych

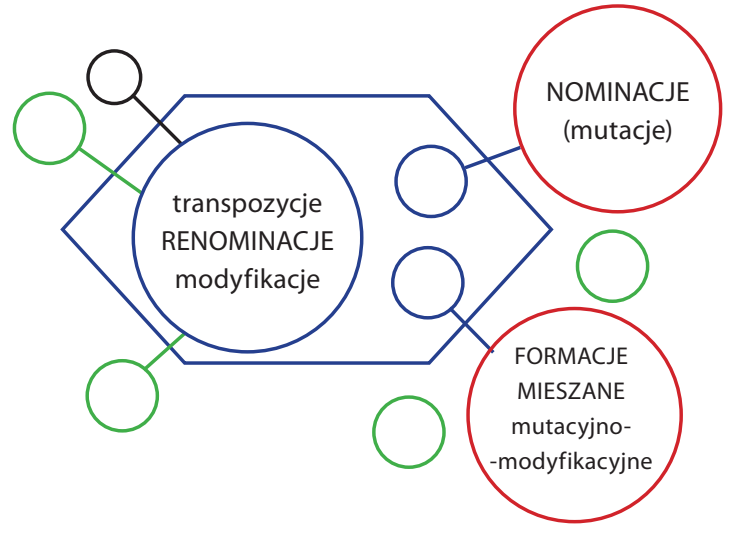

Przed przystąpieniem do dalszych rozważań należy odnieść się (z konieczności zwięźle) do zagadnień motywacji i wielomotywacyjności, decydują one bowiem nie tylko o postaci wydzielanych formantów, lecz przede wszystkim o ich funkcji i przypisaniu derywatów do danej klasy derywacyjnej (nominacji, renominacji lub formacji mieszanych). Dotyczy to zwłaszcza derywatów typu aptekarka 'aptekarz kobieta' lub 'kobieta pracująca w aptece', staruch 'o starcu pejoratywnie' lub 'o starym człowieku pejoratywnie', pijaczyna 'o pijaku z politowaniem' lub 'o tym, kto pije, z politowaniem', bieganina 'chaotyczne bieganie' lub 'chaotycznie biegać'. Wydaje się, że obydwa typy parafraz są równoprawne, gdyż „dobrze oddają znaczenie derywatu” (GWJP: 386). Jednakże uznanie dwumotywacyjności (motywacji równorzędnych) przykładowych derywatów nie rozstrzyga o ich przynależności do danej grupy formacji. O klasyfikacji derywatu decydować musi zatem motywacja podstawowa, za którą uznaję motywację bezpośrednią (por. ibid.), tj. wskazującą na podstawę bliższą derywatowi formalnie, a w odniesieniu do omawianych przykładów także semantycznie (rzeczowniki starzec, pijak, bieganie, nie zaś przymiotnik stary i czasowniki pić, biegać $)^{19}$. A zatem derywaty staruch, pijaczyna, bieganina uznamy nie za for-

18 Ewentualnie ambiwalencja emocjonalna.

19 Zgodnie z tym pierwszy derywat powstał na drodze derywacji wymiennej, drugi sufiksacji, trzeci zaś sufiksacji z towarzyszeniem alternacji. 
macje mieszane, powielające nominację już wyróżnionych językowo pojęć 'osoby starej', 'osoby nadużywającej alkoholu' i 'czynności biegania', lecz za ich renominacje tworzone od derywatów nazywających te pojęcia. W pewnych przypadkach pozwala to ograniczyć liczbę nieregularnych typów słowotwórczych, a więc wydzielać formanty -ynal/-ina w bieganina i pijaczyna (nie zaś -anina, -aczyna) ${ }^{20}$, w innych jednak mnoży je, por. pi-jatyka, bi-jatyka.

Inaczej proponuję traktować derywaty nazywające kobiety, typu aptekarka, malarka, grubaska. Podstawową motywacją są dla nich motywacje pośrednie (apteka, malować, gruba), nie zaś bezpośrednie. Rozstrzygnięcie to dyktowane jest spostrzeżeniami dotyczącym interpretacji znaczeniowej takich derywatów dokonywanej przez użytkowników języka ${ }^{21}$. Otóż przeprowadzane przeze mnie „wywiady” słowotwórcze (ze studentami polonistyki i pedagogiki) dowodzą, że za podstawy słowotwórcze takich formacji uznają oni odpowiednie rzeczowniki ('kobieta pracująca w aptece'), czasowniki ('kobieta, która maluje') i przymiotniki ('gruba kobieta'), a nie odpowiadające im derywaty nazywające mężczyzn. Dlatego też omawiane derywaty (a tym bardziej takie jak szafiarka $\leftarrow s z a f a$, nie zaś $\leftarrow{ }^{\star}$ szafiarz) należy zaliczać do formacji mieszanych nominacyjno-modyfikacyjnych.

Wróćmy do pragmatyki w słowotwórstwie. Jak wspomniano, formacje pragmatyczne występują w dwóch podstawowych odmianach, jako derywaty emocjonalne i wartościujące oraz jako derywaty stylistyczne (nacechowane stylistycznie). Formanty w tych pierwszych mogą:

- wnosić wartość dodatnią, np. kawusia, spanko, ćwiczonko, strzał(ecz)ka;

- wnosić wartość ujemną, np. redaktorek, pisarzyna, urzędas, wierszydło, Polaczek, bieganina;

- wzmacniać wartość ekspresywną podstawy, np. tatuś, pijaczysko, chamidło, dupeczek ${ }^{22}$;

- łagodzić wartość tematu słowotwórczego nacechowanego pejoratywnie, np. wyrko, żarełko, kłamczuszek, wojenka, głupotka;

- wprowadzać ambiwalencję ekspresywną, np. pijaczek, pijaczyna, koszulina, (gwarowe $\dot{z} y t k o$ ).

Niektóre z powyższych derywatów cechuje jednoczesne nacechowanie potocznością, co zawdzięczają one formantom (urzędas, spanko), a także podstawom (wyr$k o$, strzałeczka). Formanty w derywatach stylistycznych są sygnałem ich stylowo-odmianowego ograniczenia. Wśród formacji stylistycznych trzeba wyróżnić przede

20 Także $-k o($ nie -anko) w spanko $\leftarrow$ spanie, $-y n a($ nie -arzyna) $\mathrm{w}$ pisarzyna $\leftarrow$ pisarz itp.

21 Podobne postępowanie, tj. uwzględnianie w opisie słowotwórczym interpretacji słowotwórczych użytkowników, możliwe i wskazane jest niekiedy w badaniach słowotwórstwa gwarowego; szerzej na ten temat (Kurdyła 2011a: 28-33).

22 Derywaty takie jak ostatni, podobnie jak wulgaryzmy przerabiane formantami deminutywnymi, są bardziej jeszcze pogardliwe niż ich podstawy. Kolejną cechą takich derywatów, wskazaną przez S. Grabiasa (1978: 93), jest ironiczność. 
wszystkim częste derywaty potoczne, także młodzieżowe, slangowe, np. uciekacja $\leftarrow$ $u c i e c z k a, w o z i d ł o \leqslant$ wóz 'samochód' i powyższe przykłady. Należą do nich również uniwerbizmy (w których wartość stylistyczna formantów jest wręcz kategorialna), np. ogólniak, skarbówka, sementalka 'krowa rasy sementaler', derywaty typu pewueszetka $\leftarrow P W S Z$ 'Państwowa Wyższa Szkoła Zawodowa', także ucięcia typu cze, nara, $w$ porzo, spoko, piona 'piątka'. Trzeba wydzielić również rzadkie derywaty podniosłe (poetyckie) typu tęsknica, szablica, ziemica, żywot. Wydaje się też, że zróżnicowane odmianowo są leksemy typu marchew, grusza, firana, skarpety i marchewka, gruszka 'drzewo', firanka, skarpetki - pierwsze mają charakter oficjalny, „słownikowy” (czy lepiej „encyklopedyczny”), bliższy odmianie wzorcowej polszczyzny, drugie - bliższy odmianie potocznej.

Prócz derywatów nominacyjnych i renominacyjnych istnieją dwie klasy formacji mieszanych: 1) formacje nominacyjno-modyfikacyjne, czyli derywaty nominacyjne $\mathrm{z}$ jednoczesną modyfikacją typu gatunkowego i/lub pragmatycznego oraz 2) renominacje złożone, czyli: a) derywaty transpozycyjno-modyfikacyjne - derywaty $\mathrm{z}$ formantami o funkcji transpozycyjnej i funkcji modyfikacyjnej typu pragmatycznego (rzadkie) i b) modyfikacje mieszane - derywaty $\mathrm{z}$ formantami o dwóch lub trzech funkcjach modyfikacyjnych typu gatunkowego i/lub pragmatycznego (częstsze). Wyjaśnienia wymaga połączenie funkcji nominacyjnej z modyfikacją, zwłaszcza że wcześniej zarzucałem I. Kaproń-Charzyńskiej niesłuszność łączenia transpozycji z mutacją. Czy zatem mogą istnieć derywaty $\mathrm{z}$ formantami o funkcji jednocześnie nominacyjnej („nazywającej”) i renominacyjnej („ponownie nazywającej”)? Tak, choć określenie nominacyjno-renominacyjne wprowadza pewien zamęt. W derywatach typu pracuś, dzieciuch 'ten, kto zachowuje się jak dziecko' (symilatywum) dokonuje się nominacja jakiegoś pojęcia, jednocześnie jest ono - jak by się dziś powiedziało - „profilowane” - ekspresywnie lub gatunkowo. Słowotwórcze operacje semantyczne mutacja : modyfikacja nie powinny być traktowane jako konkurujące ze sobą, wykluczające się, lecz jako operacje komplementarne, którymi objęte są inne kategorie pojęciowo-leksykalne (zob. Kurdyła 2011a: 79-82), zwane przez S. Grabiasa (1981b: 142) - za Olgą Rewziną - polami słowotwórczymi.

Derywaty z kategorialnym składnikiem pragmatycznym należą do obydwu klas formacji mieszanych, czyli do:

1) formacji nominacyjno-modyfikacyjnych:

- ekspresywnych nazw subiektów (żyjątko, pracuś, dzieciuch);

- żeńskich nazw ekspresywnych (modnisia, latawica, pomponiara);

- żeńskich nazw stylowych (filolożka, pedagożka, architektka, marszałkini, ministra); taka klasyfikacja derywatów wymaga wyjaśnienia, jest bowiem dyskusyjna. Obecnie formacje tego typu bywają interpretowane jako nacechowane potocznością, czasem nawet pejoratywnością; jednak dla innych są one pragmatycznie neutralne (zróżnicowanie tych opinii powodowane jest czynnikami pozajęzyko- 
wymi, światopoglądowymi itd.). Póki istnieje wariantywność typu pedagożka: (pani) pedagog, właściwsze wydaje się traktowanie tych pierwszych jako wariantów nacechowanych, zwłaszcza, że od kilkudziesięciu lat budzą one dyskusje, nie tylko wśród językoznawców. Tylko niektóre feminatywa osobowe, od dawna występujące w polszczyźnie (jak np. dyrektorka, sędzina), można uznać za modyfikacje typu pojęciowego;

- nazw fachowych (są to derywaty należące do różnych terminologii i słownictwa erudycyjnego, np. formacje z sufiksem -izm: historyzm, absolutyzm, -acja: pasteryzacja, -yka: robotyka czy quasi-złożenia z członem -logia ${ }^{23}$. Derywaty typu tumiwisizm cechuje odczuwalny kontrast stylistyczny formantu i podstawy, przez co zyskują nacechowanie emocjonalne, a podstawowa wartość stylistyczna formantów zostaje ujęta w cudzysłów) ${ }^{24}$;

2) formacji renominacyjnych złożonych:

a) transpozycyjno-modyfikacyjnych:

- ekspresywnych nazw cech (cienizna, malizna, normalka);

- stylowo-ekspresywnych nazw procesów (młodzieżowe i slangowe derywaty typu ustawka; w gwarach także uroczyste nazwy czynności typu sprosiny, przenosiny, spleciny, którym towarzyszy ponadto zawężenie znaczenia podstawy (zob. m.in. Kurdyła 2011a: 59-60));

- modyfikacyjne nazwy czynności i cech (zaliczam tu tak zwane transpozycje nieregularne typu: pijatyka, pijaństwo, bijatyka, bitwa (GWJP: 394-398). Derywaty pijatyka, bijatyka, bitwa to nie nazwy samych czynności, lecz raczej akcji, zdarzeń, których centrum są dane czynności; podobnie pijaństwo to nie nazwa czynności, lecz nazwa skłonności do picia. Możliwa jest też interpretacja mutacyjna takich derywatów, por. nazwy zjawisk charakteryzowanych przez czynności i cechy (ibid.: 416));

b) modyfikacyjnych mieszanych:

- nazw ekspresywno-stylistycznych (są to środowiskowe derywaty ekspresywne typu, złocisz, zet $\leftarrow$ złoty 'pieniądz', lasencja $\leftarrow$ laska - derywat $\mathrm{z}$ określonym wyżej stylistycznym kontrastem formantu i podstawy; heteromorficzne stylistycznie derywaty typu gdybologia, gdybacja $\leftarrow$ gdybanie; taki charakter mają także okazjonalizmy typu lodejszyn 'lodówka', propagandówa $\leftarrow$ propaganda; może do tej klasy, a nie do derywatów stylistycznych, należałoby zaliczyć for-

23 Warto może przytoczyć tu celne i zwięzłe spostrzeżenie Kazimierza Wyki: „Jednocześnie na tych samych wystawach przed obrazami przystają fachowcy. Malarze, krytycy i trochę kibiców. Porozumiewają się w pół słowa, w pół terminu, w ćwierć aluzji do określonego »izmu«. Ich mowa dla otaczającej publiczności jest doskonale hermetyczna i całkowicie niepojęta" (Wyka 1977: 414).

24 Jeszcze bardziej skomplikowane stylistycznie są neologizmy poetyckie, takie jak broniologia i rakietyzm w wierszowanym opowiadaniu dla dzieci (zostały one utworzone formantami fachowymi, są jednak ironiczne, a ponadto pełnią funkcję poetycką). 
macje typu stronica, tęsknica. W gwarach do klasy tej należą także ekspresywne nazwy folklorowe typu Jasieczek, koniczek, pióreczko itp.);

- nazw ekspresywno-deminutywnych (poduszeczka, obrusik, kwiatuszek, dzieciątko);

- ekspresywno-deminutywnych nazw istot młodych (piesek, kotek, myszka, pta$\left.s z e k^{25}\right)$. W tekstach derywaty należące do tej grupy mogą występować tylko w jednym ze znaczeń (kotek - 'mały' lub 'miły', lub 'młody'), o konkretyzacji funkcji formantu decyduje zaś kontekst, który zeruje nieistotne w danym akcie komunikacji znaczenia; dokonuje się to nierzadko przez użycie pozornych pleonazmów (mały kotek, śliczny kotek, młody kotek).

Derywaty ekspresywne zaliczane tutaj do formacji mieszanych nazywa S. Grabias (1978: 90-91) formacjami sekundarnie ekspresywnymi, wobec „realizowania się innych, prymarnych funkcji (mutacyjnej, transpozycyjnej lub modyfikacyjnej) procesu derywacji”26. Czy można się zgodzić z takim stanowiskiem? Nie, funkcje pragmatyczne nie są w takich derywatach pełnione „przy okazji”, a ekspresja jest w nich równie ważna jak pozostałe cele derywacji. Bo czy w derywacji rzeczownika staruch podstawową przyczyną jest nazwanie nosiciela cechy, zwłaszcza jeśli istnieje neutralny starzec? Bynajmniej, równie ważna, a może nawet ważniejsza jest ocena.

Klasyfikacja derywatów rzeczownikowych przedstawia się zatem jak poniżej:

I. NOMINACJE (mutacje) $)^{27}$

II. RENOMINACJE:

1) transpozycje (bieganie, picie, marność, piatka);

2) modyfikacje:

A) typu gatunkowego:

a) deminutywa (stupek, kwadracik, plamka) i augmentatywa (nieliczne, np. donica, poducha);

b) nazwy żeńskie i nazwy męskie (dyrektorka, mistrzyni, pielęgniarz);

c) nazwy istot młodych (ptaszę, kocię, prosiak);

d) nazwy rodzajowe (jęzor, liścień);

e) nazwy zbiorowe (listowie, ptactwo);

B) typu pragmatycznego:

a) nazwy ekspresywne:

- dodatnie (kawusia, spanko);

- ujemne (pisarzyna, wierszydło, Polaczek);

25 Wykładnikiem niedojrzałości jest więc nie tylko paradygmat z mianownikowym -ę oraz mazowiecki sufiks - ak, ale i -ek. W gwarach taki charakter mają także formacje typu jodełka, sosenka, jabłonka 'młoda jodła', 'młoda sosna', 'młoda jabłoń'.

26 Natomiast funkcja modyfikacyjna u S. Grabiasa odpowiada funkcji modyfikacyjnej pojęciowej w proponowanej tu klasyfikacji.

27 Dla oszczędności miejsca oraz ze względu na to, iż nominacyjne kategorie słowotwórcze nie były omawiane w niniejszym artykule, nie wyróżniam ich typów także w prezentowanej klasyfikacji. Zestaw formacji mutacyjnych należy tworzyć w oparciu o strukturę predykatowo-argumentową (SPA) podstawy słowotwórczej, por. (GWJP). 
- wzmacniające wartość ekspresywną (tatuś, pijaczysko, chamidło, dupeczek);

- łagodzące wartość pejoratywną tematu (wyrko, kłamczuszek);

- ambiwalentne (pijaczek, pijaczyna, koszulina);

b) nazwy stylistyczne:

- potoczne i środowiskowe (ogólniak, nara, pewueszetka, wozidło);

- podniosłe i poetyckie (tęsknica, ziemica, żywot);

III. FORMACJE MIESZANE:

1) nominacyjno-modyfikacyjne:

- ekspresywne nazwy subiektów (pracuś, dzieciuch, żyjątko);

- żeńskie nazwy ekspresywne (latawica, modnisia, pomponiara);

- żeńskie nazw stylowe (pedagożka, architektka, marszałkini);

- nazwy profesjonalne (terminy) (historyzm, fiksacja, robotyka);

- nazwy żeńskich wykonawców czynności (nauczycielka, aptekarka, malarka);

- zbiorowe nazwy subiektów (obstawa, starszyzna) - b. rzadkie;

- nazwy młodych pomocników (stolarczyk, mularczyk) - klasa martwa;

- żeńskie i męskie nazwy pokrewieństwa (Krupina, Kurdylina, Nowakówna,

Tokarszczuk; nowsze ${ }^{28}$ Kurdyłowa, Krupowa) - klasa onomastyczna, częściowo archaiczna, a częściowo przestarzała;

2) renominacje złożone:

a) transpozycyjno-modyfikacyjne (rzadkie):

- stylowo-ekspresywne nazwy procesów lub cech (ustawka, cienizna);

- modyfikacyjne nazwy czynności i cech (pijatyka, bijatyka, pijaństwo);

- uroczyste nazwy czynności (sprosiny, przenosiny) - tylko w gwarach;

b) modyfikacje mieszane:

- nazwy ekspresywno-stylistyczne (lasencja, złocisz; w gwarach także ekspresywne nazwy folklorowe typu Jasieczek, koniczek, pióreczko);

- nazwy ekspresywno-deminutywne (poduszeczka, obrusik, kwiatuszek, dzieciątko);

- ekspresywno-deminutywne nazwy istot młodych (piesek, kotek, myszka; w gwarach także nazwy drzew jodełka, sosenka, jabłonka);

- nazwy deminutywno-rodzajowe (obrazek w książce, wózek dziecięcy, łóżeczko dziecięce).

Jak widać, funkcja pragmatyczna występuje w większości klas formacji mieszanych. Trzeba dodać, iż pragmatyka słowotwórcza nie ogranicza się do funkcji formantu lub derywatu; może być rozumiana jeszcze inaczej, jako sposób oceny „rzeczywistości będącej poza zakresem semantycznym wyrazu” (Grzegorczykowa 1978: 119). Idzie tu o takie między innymi użycia derywatów ekspresywnych: „Jeśli mówimy do dziecka: Pójdziemy spatki (spatuchny, spateńki), okryjemy się kołdereczką, weźmiemy poduszeczkę itp., to emocja na ogół nie dotyczy ani tych przedmiotów, ani czynności

$28 \mathrm{Tj}$. przeniesione z gwar lub będące rezultatem rozszerzenia typu na -owa również na nazwiska zakończone na - $a$. 
(spatki), ale jest wyrazem ogólnego pozytywnego nastroju, który staramy się wytworzyć, a także może być, i najczęściej jest, wyrazem emocji skierowanej do odbiorcy" (ibid.: 120). Z kolei derywaty typu wóda, dycha mogą być u niektórych użytkowników języka przejawem niechętnego, lekceważącego stosunku do świata (ibid.).

4. Na zakończenie powróćmy do funkcji poetyckiej, którą I. Kaproń-Charzyńska przypisuje słowotwórstwu, ale która „nie przysługuje [...] formantom słowotwórczym. Funkcja ta jest realizowana w słowotwórstwie przez nadanie leksemowi postaci odbiegającej od normy" (2007: 154), a więc przez naruszenie przezroczystości derywatu. Ponadto $z$ artykułu dowiadujemy się, iż „nie chodzi [...] o funkcję poetycką w sensie powoływania do życia utworów literackich i ich właściwości” (ibid.: 154, przyp. 13), że „obejmuje [ona] także nadawanie zabarwienia komicznego”, a „realizacją tej funkcji będzie choćby tzw. reinterpretacja zastanej struktury słowotwórczej" (ibid.: 154) - czyli nieregularna, często okazjonalna i doraźna neosemantyzacja typu ciężarówka 'kobieta ciężarna' (zob. wyżej).

Moim zdaniem nieprzezroczystość znaku, jego „dziwność”29 (por. funkcja pragmatyczna reklamowa derywatów w przyp. 1), jest cechą wszystkich formacji pragmatycznych, przy czym jest to ich atrybut częsty, lecz nie powszechny i obligatoryjny. Formacje nacechowane ekspresywnie i stylistycznie, właśnie przez to nacechowanie, przypisywane formantom, zwracają swą formą uwagę odbiorcy. Przez nacechowanie potocyzmy rażą w polszczyźnie opracowanej, publicznej, i odwrotnie, wyrazy erudycyjne rażą w komunikacji codziennej. Z kolei formacje ekspresywne są nieprzezroczyste głównie ze względu na swój ładunek emocjonalny; uwagę zwracają zwłaszcza te formacje, które można zastąpić określeniami o słabszej ekspresji (staruch - starzec, stary; brzuchacz - otyly, por. też pijaczysko - pijak, dupeczek - dupek). Zauważmy również, że pożądane między innymi w reklamie lub we współczesnej publicystyce słownictwo oryginalne, zaskakujące, aluzyjne (a więc nieprzezroczyste), mające przykuć uwagę odbiorcy ${ }^{30}$, to często (choć nie zawsze) słownictwo nacechowane ekspresywnie: gdybologia, propagandówa ${ }^{31}$, kaczoryzacja, debilizacja, lodożercy, zaformulać, łomżing, ministra. Poetyckość (nieprzezroczystość) słowa nie jest zatem odrębną funkcją słowotwórstwa, lecz funkcją towarzyszącą renominacji pragmatycznej.

Trzeba też zaznaczyć, że funkcja poetycka formantu (i słowotwórstwa) może być rozumiana bardziej dosłownie. Wspominano już o derywatach podniosłych, poetyckich, które tworzone są formantami poetyckimi sensu stricto, tj. formantami o funkcji poetyckiej 'właściwej poezji, literaturze', współtworzącymi poetykę dzie-

29 Określenie R. Grzegorczykowej (1991: 26).

30 Podejrzewam, że podobną przyczynę - skupienie uwagi odbiorcy (niekoniecznie na samym derywacie) - miało powołanie do życia tworu ministra.

31 W derywatach tego typu (także wszystkoizm, uciekacja itp.) „niezwykłość” stylistyczna jest wprowadzana przez kontrast stylistyczny podstawy i formantu. 
ła literackiego. Derywowane za ich pomocą leksemy należą do stylu artystycznego i nie występują (bądź są niezwykle rzadkie) w innych stylach i odmianach języka. Funkcję tę pełnią przede wszystkim formanty tworzące derywaty typu szablica, ziemica, tęsknica, żywot (por. np. Z gromnicy wysokiej jak sosna wyszedł z pętlica na krtani Traugutt - T. Gajcy, Widma), także charakterystyczne dla poetów młodopolskich derywaty z formantem paradygmatycznym (lub warianty rodzajowe) typu tarcz, zgliszcz, petń, ziem, kleszcz 'kleszcze' (Wyka 1977: 447-448). Pełnią ją również formanty w tych derywatach gwarowych, które notowane są wyłącznie lub głównie $\mathrm{w}$ tekstach folklorowych; bardzo często są to pozorne deminutywa pierwszego i drugiego stopnia (pióreczko, zameczek, płużeczek, koseczka itp.) ${ }^{32}$.

Funkcję poetycką w derywacji (funkcję raczej słowotwórstwa, a nie formantów) można rozumieć jeszcze inaczej, jako przejaw kreatywnej funkcji języka, umożliwiającej „kreację dzieła sztuki, a przez to dzieło kreację pewnego świata” (Grzegorczykowa 1991: 25). Na gruncie słowotwórstwa jest to zadanie przede wszystkim neologizmów literackich, takich jak sepulki Stanisława Lema lub derywaty $\mathrm{z}$ frazy: Wylazł z rowu Dusiołek, jak półbabek z łoża3. Tak definiowana poetyckość nie należy już w słowotwórstwie do pragmatyki, lecz stanowi odrębną domenę derywacji, która powinna być wydzielana obok nominacji i renominacji.

\section{Literatura}

Awdiejew A., Habrajska G., 2004, Wprowadzenie do gramatyki komunikacyjnej, t. 1, Łask. Bartmiśski J., 1973, O języku folkloru, „Z Dziejów Form Artystycznych w Literaturze Polskiej" t. XXXII, Wrocław.

BARTMIŃsKi J., 1993, Ludowy styl artystyczny, [w:] idem (red.), Encyklopedia kultury polskiej XX wieku, t. II: Współczesny język polski, Wrocław, s. 223-233.

Grabias S., 1978, Derywacja a ekspresja, [w:] T. Skubalanka (red.), Studia nad składnia polszczyzny mówionej, Wrocław i in., s. 89-102.

Grabias S., 1981a, O ekspresywności języka. Ekspresja a stowotwórstwo, Lublin.

Grabias S., 1981b, Typy derywacji i składnikowa analiza funkcji formantów, [w:] J. Bartmiński (red.), Pojęcie derywacji w lingwistyce, Lublin, s. 127-147.

32 Istnienia słownictwa (wyłącznie) folklorowego dowodzą prace wielu dialektologów, wśród nich Jerzego Bartmińskiego (1973; 1993), Jerzego Sierociuka (1990) i Józefa Kąsia (2006); zob. też praca Macieja Raka (2014).

33 Warto może wiedzieć, że Dusiołek znany jest (pod innymi imionami) w wielu kulturach i językach świata. W Polsce Dusiołka pod tą właśnie nazwą znają chłopi w różnych regionach Polski (Wyka 1977: 419-420), np. na Podkarpaciu, na dawnym obszarze łemkowskim, zwano go Hurboszem, co może mieć związek z garbem. Z kolei półbabek utworzony jest na wzór półchłopka i innych złożeń z pót-i -ek typowych dla gwar, derywowanych także od podstaw rzeczownikowych żeńskich, por. półskrzynek $\leftarrow$ pó + skrzynia, półkopek $\leftarrow$ pó $+k o p a$, północek $\leftarrow$ pó + noc (ale i pótnocka). 
GrZegorczy Kowa R., 1978, Struktura semantyczna wyrażeń ekspresywnych, [w:] M. Szymczak (red.), Z zagadnień słownictwa współczesnego języka polskiego, „Prace Językoznawcze PAN” t. 91, Wrocław, s. 117-123.

GrZegorczy Kowa R., 1991, Problem funkcji języka i tekstu w świetle teorii aktów mowy, [w:] J. Bartmiński, R. Grzegorczykowa (red.), Język a kultura, t. 4: Funkcje języka i wypowie$d z i$, Wrocław, s.11-28.

GWJP: R. Grzegorczykowa, R. Laskowski, H. Wróbel (red.), Gramatyka współczesnego języka polskiego. Morfologia, Warszawa 1999.

Heltberg K., 1964, O deminutywach $i$ augmentatywach, „Prace Filologiczne” XVIII, cz. 2, S. 93-102.

Honowska M., 1979, Ewolucja metod polskiego słowotwórstwa synchronicznego (w dziesięcioleciu 1967-1977), „Prace Komisji Językoznawstwa”, Wrocław - Warszawa - Kraków Gdańsk, nr 50.

JADACKA H., 1994, Od czego zależy aktywność słowotwórcza rzeczowników w języku polskim?, „Poradnik Językowy” z. 7, s. 1-10.

JА ковSOn R., 1989, Poetyka w świetle językoznawstwa, [w:] idem, W poszukiwaniu istoty języka. Wybór pism, t. 2, Kraków, s. 77-124.

Kaproń-Charzyńska I., 2007, Pragmatyczna funkcja formantów w opisie derywatów, „Biuletyn Polskiego Towarzystwa Językoznawczego" LXIII, s. 147-156.

Kaproń-CharzyŃska I., 2008, Klasyfikacja derywatów ze względu na funkcje formantów, [w:] S. Ondrejovič (red.), Varia XV, Bratysława, s. 280-286.

KAPRoŃ-ChARZYŃSKa I., 2011, Funkcja stylistyczna formantów słowotwórczych. Zarys problematyki, „Studia z Filologii Polskiej i Słowiańskiej” t. 46, Warszawa, s. 57-69.

KĄś J., 2006, Rozwarstwienie słownictwa w słowniku gwarowym, [w:] J. Sierociuk (red.), Gwary dziś. 3. Wewnętrzne zróżnicowanie języka wsi, Poznań, s. 135-138.

Kleszczowa K., 1981, Ograniczenia semantyczne w procesie derywacji nazw narzędzi, „Prace Naukowe Uniwersytetu Śląśkiego w Katowicach” nr 437, Katowice.

KuRdyŁa T., 2011a, Funkcje formantów rzeczownikowych w polszczyźnie ludowej (na przykładzie trzech wsi podkarpackich), „Biblioteka «LingVariów»" t. 12, Kraków.

KuRdyŁA T., 2011b, Jeszcze o derywatach tautologicznych, „LingVaria” nr 1 (11), s. 85-92.

NAGóRко A., 2007, Zarys gramatyki polskiej, wyd. 7, Warszawa.

PuZynina J., 1967, Pojęcie regularnej i nieregularnej konstrukcji morfemowej a fakty słowotwórcze, „Biuletyn Polskiego Towarzystwa Językoznawczego” XX, s. 91-102.

PuZYnina J., 1972, O pojęciu synchronicznej pochodności derywatów, [w:] eadem (red.), Problemy współczesnego słowotwórstwa a dydaktyka uniwersytecka, Warszawa, s. 49-58.

RAK M., 2014, Zróżnicowanie stylistyczne gwary w świetle statystyki leksykalnej (na materiale podhalańskim), [w:] M. Rak, K. Sikora (red.), Badania dialektologiczne. Stan, perspektywy, metodologia. Materiały konferencji naukowej „Gwara i tekst”, Kraków, 27-28 września 2013 r., „Biblioteka «LingVariów»” t. 17, Kraków, s. 157-166.

ReCzex S., 1968, Deminutiva polskie. Charakterystyka, rozwój funkcji stylistycznej, „Rocznik Naukowo-Dydaktyczny WSP w Rzeszowie” z. 3 (5), s. 373-386.

Rogowska E., 1993, Funkcja formantu słowotwórczego w rzeczownikach zbiorowych, "Zeszyty Naukowe Uniwersytetu Gdańskiego”. „Prace Językoznawcze. Filologia Polska” nr 17-18, Gdańsk, s. 205-212.

Sierociuk J., 1990, Pieśń ludowa i gwara, Lublin. 
SKARŻYŃski M., 1999, Powstanie i rozwój polskiego słowotwórstwa opisowego, Kraków. Wyка K., 1977, Bolesław Leśmian: dwa utwory, [w:] idem, Rzecz wyobraźni, Warszawa, S. $414-450$.

\section{Pragmatics in word-formative classification of nouns Summary}

The article presents a classification of Polish nominal word formations with a particular regard to derivatives with a categorial pragmatic (expressive) element. It discusses some of the existing proposals of classification, and suggests the author's own. The highest floor of the classification contains: I. nominations (mutations) and II. renominations; the latter being divided into 1. transpositions, 2 a. type modifications (feminitives, diminutives, names of young beings, etc.), and $2 \mathrm{~b}$. pragmatic modifications: emotional-evaluative, and stylistic derivatives. Also distinguished are III. mixed derivatives: 1. nominational-modificative, and 2. compound renominations. The general classification of derivatives counts transpositions and modifications as a single word-formative type that stands in opposition to mutations. Moreover, the paper makes more precise the understanding of the poetic function of word-formative affixes and word-formation in general. This function can be viewed as a variety of the pragmatic function, and more literally, as the function that tightly binds the derivative with the poetic language and with the "reality" it creates. 